\title{
PEMBATALAN TIKET HOTEL ONLINE SECARA SEPIHAK OLEH PIHAK AGODA*
}

\author{
Oleh: \\ Komang Calvin Krisna Dwipa ** \\ Ni Luh Gede Astariyani ${ }^{* * *}$ \\ Program Kekhususan Hukum Bisnis, Fakultas Hukum, \\ Universitas Udayana
}

\begin{abstract}
ABSTRAK
Dengan kemajuan teknologi yang pesat kegiatan manusia dalam hal memesan tiket hotel menjadi lebih mudah. Dalam melakukan pemesanan tiket hotel konsumen tidak perlu harus bertatap muka terlebih dahulu dengan penjual tiket hotel. Namun tidak semua kegiatan online dapat berjalan dengan mulus. Permasalahan yang diangkat didalam karya ilmiah ini sebuah kasus pembatalan tiket hotel secara sepihak yang dilakukan pihak Agoda melalui transaksi online. Karena itu dibutuhkannya kepastian hukum terhadap hak-hak dari konsumen dalam Undang-Undang Nomor 8 Tahun 1999 Tentang Perlindungan Konsumen.

Metode penelitian yang digunakan untuk jurnal ini adalah metode penelitian hukum empiris dengan cara meneliti bagaimana bekerjanya hukum di lingkungan masyarakat dengan teori yang berlaku. Hasil dari penelitian ini ialah pihak konsumen telah mendapat ganti rugi karena pihak Agoda telah membatalkan tiket hotel secara sepihak. Penulisan jurnal ini bertujuan untuk mengetahui perlindungan hukum terhadap konsumen tentang pembatalan perjanjian jual beli online secara sepihak.

\section{Kata Kunci: Perlindungan Konsumen, Pembatalan Sepihak,} Online
\end{abstract}

\section{ABSTRACT}

With the quick progress og technologies human activities in terms of ordering hotel ticket to be easy. In ordering hotel ticket the consumer

${ }^{*}$ Penulisan karya ilmiah yang berjudul Pembatalan Tiket Hotel Online Secara Sepihak Oleh Pihak Agoda ini merupakan bukan ringkasan skripsi (di luar skripsi).

${ }^{* *}$ Komang Calvin Krisna Dwipa adalah penulis pertama dalam penulisan karya ilmiah ini, selaku Mahasiswa Fakultas Hukum Universitas Udayana.

${ }^{* * *} \mathrm{Ni}$ Luh Gede Astariyani adalah penulis kedua dalam penulisan karya ilmiah ini, selaku Dosen Fakultas Hukum Universitas Udayana 
don't need to be face to face before with the hotel ticket seller. But not all online activities can run smoothly. The problem appointed in this scientific work a case cancellation of hotel ticket unilaterally conducted by Agoda trough online transaction. Therefore the need for legal certainty to rights of consumer in Constitution Number 8 Year 1999 About Consumer Protection.

The research method used for this journal is empirical legal research method by researching how the law is worked in community environment. The result of this research is the consumer already get compensation because Agoda party has cancel the hotel ticket unilaterally. Writing this journal have a purpose for know law protection to consumer about cancellation of unilateral online sale and purchase agreement.

\section{Keyword: Consumer Protection, Unilateral Cacellation, Online.}

\section{PENDAHULUAN}

\subsection{Latar Belakang Masalah}

Di era globalisasi seperti sekarang ini masyarakat kebanyakan sudah melek terhadap perkembangan teknologi mulai dari anak-anak hingga orang yang sudah lanjut usia sekali pun. Perkembangan teknologi sangat membantu kehidupan sehari-hari masyarakat dalam melakukan kegiatannya. Salah satu teknologi yang sangat membantu di era sekarang ini adalah internet, dimana didalam dunia internet ada berbagai macam kemudahan diberbagai bidang dan segala aspek. Internet tidak hanya memudahkan masyarakat dalam bidang komunikasi melainkan juga dalam bidang transaksi jual beli atau yang biasa disebut dengan e-commerce (jual beli online). Ada beragam jenis transaksi jual beli baik itu barang maupun jasa bagi pengguna internet atau dalam kasus ini adalah orang-orang yang berperan sebagai konsumen. Produk barang dan jasa yang digunakan untuk memenuhi kebutuhan hidup manusia semakin lama semakin canggih, sehingga timbul kesenjangan terhadap kebenaran informasi dan daya tanggap konsumen, dimana kondisi tersebut kemudian 
menempatkan konsumen dalam posisi yang lemah. ${ }^{1}$ Oleh sebab itu perlindungan terhadap hak-hak yang dimiliki oleh para konsumen harus dijunjung tinggi dan harus dicermati oleh para pelaku usaha agar tidak terjadinya hal-hal diluar dari konteks jual beli. Perlindungan terhadap konsumen dipandang secara material maupun secara formal makin terasa sangat penting, mengingat makin lajunya ilmu pengetahuan dan teknologi yang merupakan motor penggerak bagi produktifitas dan efisiensi produsen atas barang atau jas yang dihasilkannya dalam rangka mencapai sasaran usaha. ${ }^{2}$ Pihak konsumen berhak untuk mendapatkan perlindungan hukum dari pemerintah apabila terjadipelanggaran yang dilakukan oleh pelaku usaha yang merugikannya. Pemerintah Indonesia telah mengeluarkan sebuah peraturan untuk hak-hak bagi konsumen melalui pembentukan undang-undang yaitu Undang-Undang Perlindungan Konsumen yang selanjutnya disingkat UUPK. ${ }^{3}$

Di zaman yang sudah didominasi oleh internet, sebagian besar masyarakat Indonesia dipermudah dengan adanya aplikasi atau web yang melayani pembelian tiket kamar baik itu penginapan biasa maupun hotel. Pembookingan kamar penginapan dilakukan tanpa melalui tatap muka melainkan melalui smartphone maupun PC masing-masing. Para konsumen bebas memilih penginapan yang tertera pada situs online kegiatan usaha dalam bidang travel tersebut (Agoda) sesuai dengan budget yang dimiliki, yang disesuaikan lagi dengan tanggal check in, berapa hari akan menginap, serta total kamar yang diperlukan. Kemudian konsumen mengisi data diri

\footnotetext{
${ }^{1}$ Celina Tri Siwi Kristiyanti, 2011, Hukum Perlindungan Konsumen, Sinar Grafika, Jakarta, h. 4.

${ }^{2}$ Ibid, h. 5.

${ }^{3}$ Zulham, 2016, Hukum Perlindungan Konsumen, Kencana, Jakarta, h. 4.
} 
pribadi yang selanjutnya harus mentransfer total biaya yang sudah ditentukan dengan metode pembayaran yang sudah dipilih dalam durasi waktu yang sudah ditentukan. Jika pembayaran sudah terkonfirmasi maka tiket pembookingan kamar penginapan akan terbit sesuai dengan identitas konsumen yang sudah memesan.

Konsumen yang bernama Angga Aditya Atmadilaga telah melakukan pembookingan kamar hotel (Resto Apung) sebanyak 2 kamar pada hari sabtu tanggal 20 April 2019 jam 09.00 wita untuk dihari yang sama melalui aplikasi Agoda, dan membayar melalui kartu kredit. Dimana status transaksi tersebut sudah dikatakan berhasil melalui aplikasi Agoda dan tiket booking kamar sudah terbit. Namun setelah didatangi ke hotel tersebut nama pemesan tidak terdaftar sebagai tamu, padahal pihak konsumen sebenarnya sudah memenuhi aturan pemesanan dari aplikasi tersebut dan memesan sesuai dengan kamar yang tersedia, selain itu tiket booking hotel juga sudah terbit. Pihak Agoda telah membatalkan sepihak tiket tersebut, dalam hal ini pihaknya telah merugikan konsumen karena pembatalan tiket disampaikan setelah pembayaran selesai dan tiket hotel diterbitkan. Melalui pengalaman tersebut penulis tertarik untuk membahas perlindungan konsumen tentang pembatalan tiket hotel secara sepihak oleh pelaku usaha Agoda.

\subsection{Rumusan Masalah}

1. Bagaimana tanggung jawab dari pihak agoda sebagai pelaku usaha terkait pembatalan tiket hotel secara sepihak?

2. Tindakan apa yang dapat dilakukan konsumen yang telah dirugikan karena pembatalan tiket secara sepihak terkait dengan hukum?

\subsection{Tujuan Penelitian}


Tujuan dari tulisan ini ialah untuk mengetahui tanggung jawab dari pihak Agoda yang telah membatalkan tiket hotel secara sepihak terhadap konsumen yang mengalami kerugian dan perlindungan hukum yang didapat oleh konsumen terkait pembatalan tiket secara sepihak menurut Undang-undang Perlindungan Konsumen.

\section{ISI MAKALAH}

\subsection{Metode Penelitian}

Dalam penyusunan jurnal ini penulis menggunakan suatu penelitian hukum yaitu metode empiris dengan objek kajian menggunakan perbandingan antara teori yang ada dengan setiap kejadian hukum yang terjadi ditengah-tengah kehidupan masyarakat yang di implementasikan. ${ }^{4}$ Jadi didalam penelitian ini mencakup ketidak sesuaian antara praktek yang terjadi dilingkungan masyarakat dengan teorinya.

\subsection{Hasil dan Analisis}

\subsubsection{Tanggung Jawab Dari Pihak Agoda Sebagai Pelaku Usaha Terkait Pembatalan Tiket Hotel Secara Sepihak}

Agoda adalah salah satu perusahaan internet yang menyediakan layanan reservasi properti hotel maupun penginapan secara online baik itu melalui smartphone maupun PC yang difokuskan terutama untuk kawasan Asia Pasifik. Basis operasional perusahaan ini ada di Negara-negara bagian Asia Tenggra yaitu Thailand, Singapura, dan Filipina. Agoda memiliki dua platform untuk mengaksesnya, yaitu melalui web yang bisa diakses menggunakan personal computerdan juga melalui aplikasi jika ingin mengakses melalui gadgetyang memiliki sistem operasi android

\footnotetext{
${ }^{4}$ Ade Saptomo, 2009, Pokok-Pokok Metodologi Penelitian Hukum Empiris Murni, Universitas Trisakti, Jakarta, h. 43.
} 
maupun ios,yang dapat didownload melalui playstore dan appstore. Pendapat beberapa situs yang sudah mereview Agoda menyatakan, Agoda mempunyai banyak sekali promo pada harga sewa kamar yang mereka tampilkan. Bahkan promo yang dilakukan oleh pihak Agoda bisa memberi diskon sangat besar-besaran, bisa sampai $80 \%$ dari harga aslinya, baik itu dari kamar penginapan yang paling murah maupun kamar dari hotel bintang lima sekalipun.

Berhubung promo-promo yang disuguhkan dari pihak Agoda sangat menggiurkan bagi para konsumen, dimana konsumen dapat menginap ditempat yang nyaman dengan tidak merogoh kocek yang besar, sehingga dianggap dengan menggunakan Agoda kita bisa mendapatkan kamar hotel dengan harga murah. Serta Agoda juga dianggap sebagai agen penjualan kamar hotel yang bisa dipercaya karena didalam sistem pemesanan hotel, batas waktu untuk melunasi pembayaran tiket hotel akan muncul secara otomatis dan dihitung mundur setelah kita menyelesaikan prosedur pemesanan tiket hotel. Kemudian jika konsumen tidak melakukan pembayaran sampai batas waktu yang sudah ditentukan untuk melunasi pembayaran habis maka pesanan tersebut akan otomatis diblokir oleh sistem.

Didalam proses perjanjian jual beli, termasuk perjanjian jual beli online atau transaksi elektronik harus didasari dengan itikad baik dari pihak-pihak yang terkait dalam perjanjian tersebut yaitu pihak pelaku usaha maupun pihak konsumen. 5 Secara umum konsumen dan produsen memiliki hubungan hukum yang erat, dimana produsen memproduksi sebuah barang yang menjadi

${ }^{5}$ I Gede Krisna Wahyu Wijaya, "Penerapan Asas Itikad Baik Dalam Perjanjian Jual Beli Online”, Jurnal Fakultas Hukum Universitas Udayana, hal. 6. 
keperluan konsumen, dan konsumen menggunakan atau menghabiskan nilai guna barang yang diproduksi oleh produsen guna mendapat keuntungan. Dalam kasus ini Angga Aditya Atmadilaga selaku konsumen yang melakukan transaksi dengan pihak Agoda selaku pelaku usaha, sudah membentuk perjanjian yang mengikat diantara kedua belah pihak secara sah. Kedua belah pihak telah memenuhi syarat-syarat terjadinya suatu perjanjian dalam pasal 1320 KUHPer yang terdiri dari; (1) Kesepakatan untuk mereka yang telah melakukan perjanjian; (2) Kecakapan kedua belah pihak dalam melakukan perjanjian; (3) Suatu pokok dari persoalan tertentu; (4) Suatu sebab yang tidak terlarang. Lalu akan muncul suatu peraturan yang harus ditaati oleh para pihak yang diakibatkan dari persetujuan yang dibuatnya. Didalam pasal 1338 KUHPer menyatakan suatu perjanjian tidak akan dapat ditarik lagi selain dikarenakan kesepakatan kedua belah pihak, serta perjanjian tersebut harus dilakukan dengan itikad baik.

Didalam kasus ini terjadi sebuah kerugian yang diterima pihak konsumen karena pelanggaran yang dilakukan pihak pelaku usaha, dimana pelaku usaha telah membatalkan tiket hotel secara sepihak yang sudah dipesan sebelumnya oleh pihak konsumen. Karena hal tersebut timbullah sengketa konsumen, yang merupakan sengketa yang mencakup segala aspek hukum karena pelanggaran yang telah dilakukan terhadap hak-hak konsumen. ${ }^{6}$ Pada pasal 1480 KUHPer diatur tentang seorang konsumen bisa menuntut pembatalan suatu pembelian apabila penyerahan dari barang yang dibeli tidak dapat direalisasikan karena kelalaian pihak penjual. Disini pihak

\footnotetext{
${ }^{6}$ Shidarta, 2006, Hukum Perlindungan Konsumen Indonesia, Grasindo, Jakarta, h. 80.
} 
konsumen sudah memenuhi kewajibannya dengan membayar tiket hotel sesuai dengan nominal yang tertera pada web Agoda dan pihak Agoda sebagai pelaku usaha memiliki kewajiban untuk memberikan kamar hotel yang sudah dipesan, tetapi pihak Agoda justru membatalkan secara sepihak pemesanan kamar tersebut setelah tiket hotel sudah muncul yang berarti pihak Agoda sudah tidak memenuhi suatu perikatan dan merugikan konsumen (pasal 1235 KUHPer). Tindakan jika suatu perikatan tidak dipenuhi didalam isi dari pasal 1267 KUHPer menyatakan akan timbul akibat ialah; pelaksanaan perjanjian; pelaksanaan dan ganti rugi; ganti rugi saja; ganti rugi dan pembatalan. ${ }^{7}$

Pasal 19 UUPK menjelaskan bahwa pihak Agoda selaku pelaku usaha berkewajiban untuk memberi ganti rugi kepada konsumen atas kerugian yang dialami konsumen karena telah menggunakan jasa yang dijual pihak Agoda. Jadi pihak konsumen berhak menuntut pelaku usaha untuk mendapat ganti kerugian yang dikarenakan pelaku usaha melakukan wanprestasi dan berdasarkan perilaku melanggar hukum yang dilakukannya.Karena pembatalan tiket hotel secara sepihak yang dilakukan pihak Agoda, maka pihak Agoda wajib bertanggung jawab dengan mengganti kerugian yang dialami oleh pihak konsumen.

Jika dilihat dari hasil wawancara yang telah dilakukan dengan Angga Aditya Atmadilaga sebagai pihak konsumen telah didapatkan informasi bahwa, pihak Agoda sudah melakukan ganti rugi berupa uang yang senilai dengan nominal yang telah dibayarkan oleh Angga untuk memesan kamar hotel. Hal tersebut dapat dilihat dari email

\footnotetext{
${ }^{7}$ Liberty Sinaga, 2018, "Pembatalan Perjanjian Jual Beli Online Secara Sepihak Oleh Lazada.Co.Id (Studi Kasus)”, Jurnal Fakultas Hukum Universitas Udayana Bali, Vol. 06 No. 04 Th. 2018, h. 3.
} 
yang telah masuk ke akun konsumen tentang pembatalan tiket tersebut, Agoda selaku pelaku usaha akan segera melakukan pengembalian dana sebesar nominal yang telah dibayar oleh konsumen melalui sistem transfer antar bank. Pihak konsumen tetap mendapatkan kerugian diakibatkan dari tindakan yang dilakukan pihak Agoda namun tidak terlalu banyak, karena pihaknya telah bertanggung jawab dengan sudah melakukan ganti rugi kepada pihak konsumen.

\subsubsection{Tindakan Yang Dapat Dilakukan Konsumen Yang Telah Dirugikan Karena Pembatalan Tiket Secara Sepihak Terkait Dengan Hukum}

Setiap lapisan masyarakat Indonesia tidak perduli itu dari kalangan menengah kebawah maupun menengah keatas memiliki hak yang sama untuk mendapat perlindungan hukum. Perlindungan hukum adalah salah satu yang termasuk didalam hak asasi manusia yang wajib diperoleh dari pemerintah berlandaskan kebijakan hukum untuk menjadi jaminan hak konstitusional sebagai warga negara guna mendapat jaminan keadilan, kepastian hukum, dan daya guna seluruh masyarakat Indonesia berlandaskan Pancasila dan UUD NRI 1945.8Jadi dapat diartikan perlindungan hukum adalah suatu perlindungan yang didapat dari perangkat hukum yang memiliki sifat preventif ataupun represif, maupun itu yang tidak tertulis atau tertulis yang diperoleh bagi semua subjek hukum. Sebenarnya secara tidak langsung hukum akan memberikan perlindungan kepada setiap hubungan hukum atau segala aspek pada kehidupan masyarakat yang sudah diatur oleh hukum itu sendiri. Oleh karena itu hukum

\footnotetext{
${ }^{8}$.Philipus M. Hadjon, 1987, Perlindungan Hukum Bagi Rakyat Indonesia,Bina Ilmu, Surabaya, h. 25
} 
sudah sejatinya wajib memberikan perlindungan kepada setiap pihak yang sesuai dengan status hukumnya karena semua orang mempunyai kedudukan yang sama dimuka hukum.

Sidobalok berpendapat tentang arti dari hukum perlindungan konsumen merupakan hukum dan segala dari peraturan yang mengontrol tentang hak-hak dan kewajiban-kewajiban dari konsumen dan produsen yang ada pada usahanya untuk melengkapi keperluannya dan mengatur segala upaya-upaya agar timbulnya perlindungan hukum kepada kepentingan konsumen. Menurut Undang-undang Nomor 8 tahun 1999 tentang Perlindungan Konsumen, menyatakan perlindungan konsumen merupaka semua upaya yang memastikan adanya kepastian hukum agar memberikan perlindungan terhadap konsumen. Segala hak dan kewajiban dari konsumen maupun produsen atau pelaku usaha serta langkahlangkah menjalankan kewajiban dan mempertahankan haknya diatur oleh hukum perlindungan konsumen. ${ }^{9} \mathrm{Jadi}$ keberadaan dari perlindungan konsumen sangat penting agar bisa mengatasi kerugian yang didapat dari pihak konsumen karena pembatalan secara sepihak yang dilaksanakan oleh pihak pelaku usaha Agoda itu.

Berdasarkan Pasal 4 UUPK yang menjabarkan tentang hak-hak yang diperoleh oleh pihak konsumen, dalam huruf $\mathrm{h}$ dijelaskan bahwa konsumen berhak diberikan ganti rugi jika sebuah jasa yang diberikan tidak sesuai dengan hal yang sudah diperjanjikan atau tidak sebagaimana mestinya. Kemudian jika terjadi sebuah pelanggaran mengenai hak-hak konsumen yang mengakibatkan timbulnya sengketa, dalam penyelesaiannya yang terkandung pada

${ }^{9}$ Sidobalok, 2014, Hukum Perlindungan Konsumen di Indonesia, Citra Aditya Bakti, Bandung, h. 37 
UUPK ada penyelesaian melalui pengadilan maupun secara damai atau menggunakan sistem konsiliasi, mediasi, dan arbitrase (penyelesaian diluar pengadilan). Pembatalan secara sepihak oleh pihak Agoda sebagai pelaku usaha terhadap tiket hotel yang sudah dipesan oleh konsumen itu disebabkan karena tidak tersedianya kamar hotel yang sudah dipesan ketika tiket hotel tersebut sudah terbit. Menurut ketentuan dari isi Pasal 9 ayat (1) huruf e UUPK, tentang larangan agar pelaku usaha untuk tidak menawarkan penawaran baik promosi ataupun iklan kepada sebuah jasa secara tidak benar atau tidak sesuai seakan-akan jasa yang ditawari tersebut masih tersedia. Jadi pihak Agoda sudah melakukan tindakan yang sesuai dengan unsur yang terkandung pada isi dari Pasal 9 ayat (1) huruf e UUPK tentang larangan terhadap mengiklankan layanan jasa menjual kamar hotel yang sebenarnya kamar hotel tersebut sudah tidak tersedia. Perilaku dari pihak Agoda tersebut dapat dituntut karena perbuatan wanprestasi yang bisa dikenai pidana sesuai pada prosedur yang berlaku. ${ }^{10}$

Menurut UUPK upaya hukum yang bisa dilakukan karena kerugian yang dialami pihak konsumen untuk menyelesaikan kasus ini dengan penyelesaian diluar pengadilan (non litigasi). Dalam menyelesaikan sengketa diluar pengadilan pihak konsumen dapat melakukan melalui jalur alternative dispute resolution (ADR) ke lembaga yang berwenang salah satunya adalah Badan Penyelesaian Sengketa Konsumen (BPSK). Sehingga upaya hukum yang dilakukan oleh pihak Agoda untuk penyelesaian sengketanya dengan konsumen menggunakan cara negosiasi yang berarti penyelesaian diluar pengadilan. Melakukan negosiasi tersebut memiliki tujuan untuk

\footnotetext{
${ }^{10} \mathrm{Ibid}$, h. 103.
} 
mencapai kesepakatan bersama tentang bentuk ganti rugi dan tentang besarnya nominal yang sama serta tindaka tertentu agar terjamin tidak akan terulang lagi hal-hal yang merugikan pihak konsumen. Dalam kegiatan negosiasi tersebut mendapatkan hasil berupa ganti rugi yang dilakukan pihak Agoda dalam bentuk uang dengan cara di transfer melalui antar bank sesuai dengan nominal yang dibayarkan konsumen saat memesan kamar hotel.

\section{Penutup}

\subsection{Kesimpulan}

Menurut hasil pembahasan diatas, diambil beberapa kesimpulan yaitu:

1. Pihak Agoda sebagai pelaku usahamemberikan tanggung jawab tentang kerugian yang dialami pihak konsumen terkait pembatalan tiket hotel tersebut yang didasari oleh prinsip tanggung jawab atas tindakan wanprestasi (breach of warranty). Hal tersebut terkandung pada Pasal 19 UUPK yang berisi wajib tanggung jawab dengan memberikan ganti rugi yang dialami oleh pihak konsumen. Fakta dari kasus ini, Angga Aditya Atmadilaga sebagai konsumen sudah mendapatkan ganti rugi akibat kerugian yang dialaminya dengan pengembalian uang sesuai dengan nominal yang sudah dibayarkan pihaknya untuk memesan kamar hotel.

2. Perlindungan hukum terhadap konsumen tentang pembatalan tiket hotel secara sepihak oleh pihak Agoda ada pada Pasal 4 dan Pasal 9 UUPK. Dengan ketentuan tersebut didapatkan upaya hukum untuk menindak lanjuti kasus ini yang didasari UUPK karena kerugian yang dialami pihak konsumen dapat dilalui dengan cara non litigasi. Menurut hasil wawancara yang telah 
dilakukan upaya hukum tersebut dilakukan dengan cara negosiasi antara pihak Agoda sebagai pelaku usaha dengan Angga Aditya Atmadilaga sebagai pihak konsumen.

\subsection{Saran}

Seharusnya pihak Agoda bertindak lebih teliti untuk tidak memperlihatkan pemilihan kamar hotel yang sebenarnya sudah tidak tersedia dari pihak hotelnya. Yang mengakibatkan tidak akan terjadinya kerugian terhadap konsumen seperti pembatalan tiket hotel secara sepihak yang dilakukan pihak Agoda sendiri.

\section{DAFTAR PUSTAKA}

\section{Buku}

Hadjon,PhilipusM.,1987,PerlindunganHukumBagiRakyat Indonesia,Binallmu,Surabaya.

Kristiyanti, Celina Tri Siwi, 2011, Hukum Perlindungan Konsumen, Sinar Grafika, Jakarta.

Saptomo, Ade, 2009, Pokok-Pokok Metodologi Penelitian Hukum Empiris Murni, Universitas Trisakti, Jakarta.

Shidarta, 2006, Hukum Perlindungan Konsumen Indonesia, Grasindo, Jakarta.

Sidobalok, 2014, Hukum Perlindungan Konsumen di Indonesia, Citra Aditya Bakti, Bandung.

Zulham,2016,HukumPerlindunganKonsumen,Kencana,Jakarta.

\section{Jurnal Ilmiah}

Sinaga, Liberty, 2018, "Pembatalan Perjanjian Jual Beli Online Secara Sepihak Oleh Lazada.Co.Id (Studi Kasus)", Jurnal Fakultas Hukum Universitas Udayana Bali, Vol. 06 No. 04 Th. 2018 
Wijaya, I Gede Krisna Wahyu, "Penerapan Asas Itikad Baik Dalam Perjanjian Jual Beli Online", Jurnal Fakultas Hukum Universitas Udayana Denpasar

\section{Peraturan Perundang-Undangan}

Undang-undang Nomor 8 Tahun 1999 Tentang Perlindungan Konsumen (LNRI Nomor 42 Tahun 1999)

Kitab Undang-Undang Hukum Perdata 